\title{
Does efficiency of the Nordic pension system evolve after crisis?
}

\author{
Marcin Brycz \\ Department of Economics, University of Gdansk \\ Poland \\ m.brycz@ug.edu.pl.
}

Abstract. This study examines efficiency of the pension system in the Nordic countries in comparison to other European counterparts using efficiency indicators proposed by Chybalski (2016). Principal Component Analysis (PCA) is used to check weather Nordic Countries forms a cluster - it is possible to extract Nordic Countries from European Countries by their pension system efficiency before and after 2008 crisis. PCA was applied to the year 2008 and 2013 to investigate whether 2008-financial crisis changed pension system efficiency. According to our analysis pension systems in Iceland, Norway and Sweden are very efficient in terms of labour market and forms a cluster both before and after financial crisis. Denmark and Finland don't differ significantly from the rest of analysed European countries.

Keywords: pension systems, principal component analysis, Nordic countries.

JEL Classification: H12, H55, J32

\section{INTRODUCTION}

The three worlds of welfare capitalism by Espring-Anderson (1990) paid attention to the various pension systems considering different welfare systems. The Denmark, Finland, Netherlands, Norway and Sweden had the highest number of socialist traits. However, pension systems were accounted to the different groups: Norway, Sweden and 'possibly' Denmark were tied to universal system, but Finland was 'possibly' included in the corporationist group. The distinction here were based mainly on the public and private share of the system. After famous Espring-Anderson (1990) work many investigated welfare regime (i.e. Hicks \& Kenworthy, 2003), but rarely who inquired pension system regimes (Soede \& Vrooman, 2008). Soede and Vrooman (2008) used CatPCA analysis in 34 traits to categorize pension systems in EU and OCED countries. Pension system regimes were analyzed in two dimension - Private/Funded and Pension Level Wealth. They also concluded the pension regimes do not fit Espring-Anderson classification to the corporationist, liberal and universal. Denmark and Sweden were accounted to the mandatory private regime, Finland to the corporationist and Norway to moderate. On the other hand Ebbinghaus (2012) argue that pension system in the Nordic Countries represent different variations of the Beveridge-system, 
as they provide basic income and different private/public solutions through different multipilar system: mandatory public pension (Sweden), mandated occupational pension (Finland) and negotiated occupational pension in Denmark.

In the famous World Bank (1994) report introducing three-pillar pension system to replace state-run dominant scheme is suggested. Actuarial methods instead of defined benefit are also recommended. Some of Nordic Countries had pension system constructed on the multi-pillar basis many years before famous World Bank report. In Denmark earnings-related pension through agreements in the labor market was approved (process was not fully completed around 1990). In Sweden earnings related ATP pension started in the early 1960's. (NOSOSCO, 2008). Since 1990's Nordic Countries reformed their pension systems, differences among them deepen (Andersen et. al., 2014). Sweden introduced notional defined contribution with automatic balancing mechanism to maintain sustainability. Denmark increased in 2006 retirement age and introduced incentives to stay longer in the labor market. Norwegian system was widely reformed in 2011, introduction of flexible retirement age took place. In Finland dominates public pension system both means-tested and earnings related, recent reforms also introduce flexible retirement age. Icelandic pension system characterizes flexible retirement age as well. According to Soede et. al. (2004) Nordic welfare system characterizes large-scale of overall security system and moderate pension system, which means that uniqness of Nordic pension cluster is rejected. Timonen and Kautto (2014) asks if recent pension reforms changed the ideals of the Nordic model. All the residents are still covered by at least one pension scheme, however provision is tight to retirement age and career history. This is an evidence of adopting the Nordic model to raising longevity, nevertheless model loose some universalism.

Another approach to assess pension systems welfare regime apply to efficiency. Open Method Coordination goals: adequacy, financial stability and modernization of pension systems can be considered as some measure of efficiency (Chybalski, 2012). Chybalski (2015) investigate efficiency through comparison of pension system functioning such as poverty alleviation, consumption smoothing, employment in age-specific groups to pension expenditure as a share of GDP. It indicates how particular aspect of pension system influence economy, for example we assume that high pension expenditure to GDP discourage elderly to work. As high employment is desirable, the higher elderly employment in terms of pension expenditure to GDP, the system more efficient. As previously stated Nordic countries pay attention to high participation in the labor market, sustainability of the system is achieved by the universal minim pension as additional to the other pillars.

Nilsson et. al. (2016) discovered that in Sweden, after recent financial crisis raised participation of older employees, among those in low-skilled occupation. Larsen and Pedersen (2015) noted small decline in labor force participation among 60-64 years old on the onset of 2008-crisis in Sweden and Norway, but in 2013 labor force participation was higher than in 2008. That indicates at least in some of the Nordic Countries pension system reform, which were addressed to raise employment through postponing retirement were efficient. So variables reflecting efficiency in terms of labor market should be considered.

The aim of the study is to show how pension systems in the Nordic Countries were immune to the 2008 financial crisis in terms of efficiency. In the late 1980's and early 1990's financial crisis took over Swedish and Finnish economy. Norway had banking problem in the middle 1980's and recent financial crisis 2007-09 hit Icelandic economy the most among Nordic countries. Over the 1990's Nordic countries took lessons from their economic downturns and reformed their welfare regimes including pension system. Many countries followed their solution so now it is harder to find their uniqness if compared to other OECD, EU countries. As Nordic countries can be found in the same welfare state regime cluster, their pension systems' regime differs. It is worth to check weather are they similar in terms of efficiency. To do this task Principal Component Analysis is performed. 


\section{LITERATURE REVIEW}

In the early 1990's debate on restructuring pension funds rolled through United States and Europe. Many countries reformed their pension system through converting it into three pillar system, with at least one funded. As the reforms were introduced new problem arisen. Funded pension funds were said to higher return for all retires, but in the same time current generation must pay tax for past generation and save money for their own retirement (Geanakopolos, Mitchell \& Zeldes, 1998; Kalyugina et al., 2015). This example shows that the outcome of reforming pension system is dependent on current state. Orszag and Stiglitz (1999) present three categories of myths on privatization pension funds: macro, micro- and Political economy, proving that funded system is no better than unfunded.

'Pension System Efficiency' is rather new term in contrast to the 'Pension Fund Efficiency'. The latter contributes to Pension Funds' investment return, administration cost etc. (Zamuee, 2015). Chybalski (2016) states that pension system efficiency consists of pension system adequacy and costs. Pension system adequacy refers to many systems' functions: consumption smoothing, poverty alleviation, replacements ratios Grech (2013). Pension Fund Efficiency is considered as the maximum return from invested assets. Witkowska and Kompa (2017) compare pension funds investment after new regulation in Poland, concluding that saveings will be higher, when invested by the Open Pension Funds then by Social Insurance Institution Indexation. In such a case we assume that the higher rate of return on average, means Pension System advantage. Contrasting that with 'Pension System Efficiency' we would ask more questions such as administration cost, macroeconomic effects i.e. real value of saveings for retiree, compulsory saveings influence on financial bubble. A notable example one can find in Chovancova and Arendas (2015). They compared long term passive investment on money and stock market. After adjusting of inflation return rate differ between analyzed countries (Germany, USA \& Japan) - in some countries rate of return was higher, but not when adjusted for inflation. Nepp (et. al., 2018) look for pension reform optimization by effective retirement age and investment return from pension fund. In sum in Pension Funds Efficiency approach various elements of investment return are analyzed, but other macroeconomic issues are omitted. Ćábelková and Strielkowski (2013) examined the welfare state concept and the taxation as a product of culture.

Barr and Diamond (2006) defined and summarized pension system functions: consumption smoothing, insurance, poverty relief, redistribution and labor market incentives. Many possibilities of reforming pension system - multipilarity, retirement age, notational solution for different social groups matter for assessing pension system through variety of indicators. Let's look at the simple example: some pension system is efficient in labour market incentive, but not in consumption smoothing. In such a case income is consumed at young age, so not saved for maturity. The idea of multidimentional efficiency of efficiency is based on building appropriate indicators and cross-countries analysis, so to group pension system by the trait. (Chybalski, 2016).

\section{METHODOLOGY}

Chybalski (2016) proposed four static dimensions of the pension system efficiency: GDPdistribution, Adequacy, Labor market and Cost efficiency. The data were collected in the same manner (but private and public pension were taken together) than standardized and destimulants changed to stimulants (the higher the value pension system more efficient) as suggested in Chybalski (2012). Data interpretation are listed in the Table 1. 
Pension Funds Efficiency Indicators

\begin{tabular}{|c|c|c|}
\hline Variable & Interpretation & Formula \\
\hline \multirow[b]{2}{*}{ GDP_e } & \multirow[b]{2}{*}{ GDP-distribution efficiency indicator } & Pension expenditures /GDP \\
\hline & & $\overline{\text { Old - age dependency ratio }}$ \\
\hline \multirow[b]{2}{*}{ ARP_e } & \multirow[b]{2}{*}{ efficiency of poverty alleviation } & $1 /($ at - risk - of - poverty - pensioners $)$ \\
\hline & & Pension expenditures $/ G D P$ \\
\hline \multirow[b]{2}{*}{ MRI_65_e } & \multirow{2}{*}{$\begin{array}{l}\text { efficiency of consumption smoothing measured by relative median income } \\
\text { ratio }\end{array}$} & Median relative income ratio $65+$ \\
\hline & & Pension expenditures /GDP \\
\hline \multirow[b]{2}{*}{ ARR_e } & \multirow{2}{*}{$\begin{array}{l}\text { efficiency of consumption smoothing measured by aggregated replacement } \\
\text { ratio }\end{array}$} & Aggregated replacement ratio \\
\hline & & $\overline{P e n s i o n ~ e x p e n d i t u r e s / G D P}$ \\
\hline \multirow[b]{2}{*}{ AC1_e } & \multirow{2}{*}{$\begin{array}{l}\text { administrative cost of pension system expressed as a percentage of pension } \\
\text { benefits }\end{array}$} & Administrative cost \\
\hline & & Pension benefits \\
\hline \multirow[b]{2}{*}{ AC2_e } & \multirow[b]{2}{*}{ administrative cost of pension systems expressed as a percentage of GDP } & Administrative cost \\
\hline & & $\overline{G D P}$ \\
\hline \multirow[b]{2}{*}{ EMP5564e } & \multirow[b]{2}{*}{ efficiency in terms of labor market } & Employment ratio $55-64$ \\
\hline & & $\overline{\text { Pension expenditures /GDP }}$ \\
\hline \multirow[b]{2}{*}{ EMP6574e } & \multirow[b]{2}{*}{ efficiency in terms of labor market } & Employment ratio $65-74$ \\
\hline & & $\overline{\text { Pension expenditures /GDP }}$ \\
\hline \multirow[b]{2}{*}{ ARAme } & \multirow[b]{2}{*}{ efficiency in terms of labor market (male) } & Average retirement age \\
\hline & & $\overline{\text { Pension expenditures /GDP }}$ \\
\hline \multirow[b]{2}{*}{ ARAfe } & \multirow[b]{2}{*}{ efficiency in terms of labor market (female) } & Average retirement age \\
\hline & & $\overline{\text { Pension expenditures /GDP }}$ \\
\hline
\end{tabular}

Source: Chybalski (2016).

To analyze whether the Nordic countries form cluster Principal Component Analysis (PCA) is used. The task is done for the year 2008 and 2013 to capture if Nordic countries change their relative position to other European countries. As of 2017 data collected form Eurostat and OECD database are not present in many cases for recent years. Compromising sufficient observation number with contemporariness I choose 2013-data as up-to-date.

In Principal Component Analysis there are no readily criteria to test solution (Tabachnick \& Fidell, 2007, p. 607) and how many components to use (Ledesma, 2015) so interpretation criteria are the most important, however some attempts have been made. For example Kaiser-Meyer-Olkin (KMO) test measures sampling adequacy for overall data set (Kaiser, 1974).

\section{EMPIRICAL RESULTS AND DISCUSSION}

In the figure 1 components loading for all the variable are plot, those concerning labor market forms cluster, they are also highly correlated with component 1. Variables reflecting consumption smoothing and poverty alleviation are highly correlated with the component 2 . We can interpret component 1 as pension funds efficiency in terms of labor market and component 2 as consumption smoothing and poverty alleviation respectively. 


\section{Component loadings (2008)}

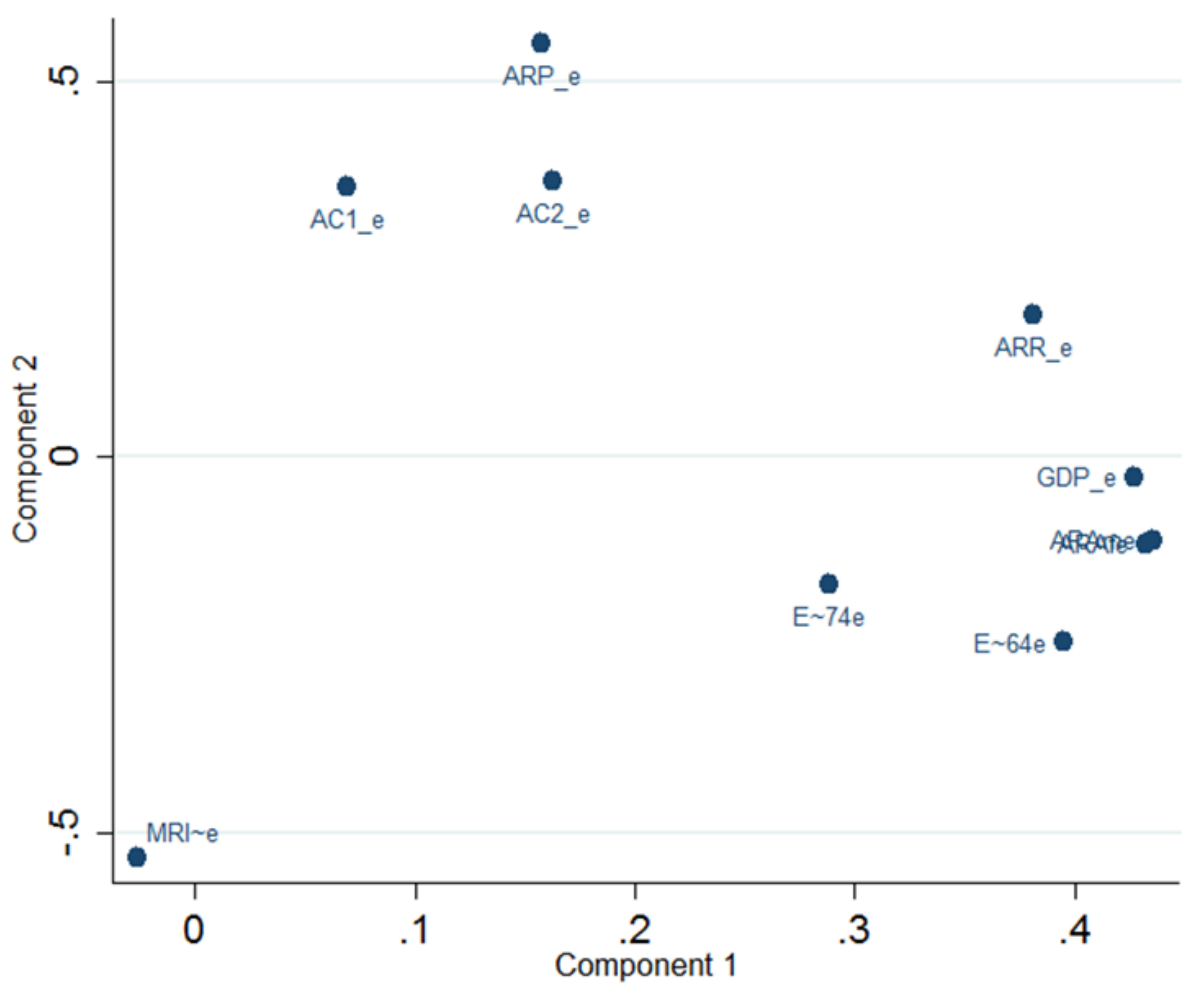

Figure 1. Component loadings in 2008, all variables

Source: Author's results.

Table 2

Principal component loadings (normalized)

\begin{tabular}{|l|c|c|c|c|}
\hline \multirow{2}{*}{} & \multicolumn{2}{|c|}{2008} & \multicolumn{2}{c|}{2013} \\
\cline { 2 - 5 } & Comp1 & Comp2 & Comp1 & Comp2 \\
\hline ARP_e & .1564 & $\mathbf{- . 9 4 8 9}$ & .4951 & $\mathbf{- . 7 8 3 9}$ \\
\hline MRI_65_e & .08393 & $\mathbf{. 9 2 2 7}$ & .01227 & $\mathbf{. 9 3 4 1}$ \\
\hline EMP5564e & $\mathbf{. 9 6 5 2}$ & .1257 & $\mathbf{. 9 5 4 5}$ & .1745 \\
\hline EMP6574e & $\mathbf{. 7 7 0 1}$ & .1845 & $\mathbf{. 8 0 1 9}$ & -.05204 \\
\hline ARAme & $\mathbf{. 9 5 7 5}$ & -.1099 & $\mathbf{. 9 3 8 2}$ & .1478 \\
\hline ARAfe & $\mathbf{. 9 4 7 4}$ & -.09206 & $\mathbf{. 9 4 0 9}$ & .1202 \\
\hline kmo & 0.6211 & & $\mathbf{k m o}$ & 0.6174 \\
\hline
\end{tabular}

Source: Author's results. Bold values indicate significant loadings at 5\%. KMO indicates Kaiser-MeyerOlkin test. 
In both year 2008 and 2013 (Table 2) the first component can be interpreted as a labour market efficiency - higher employment just before and after retirement, higher average retirement age. The second component reflects pension system adequacy: consumption smoothing and poverty alleviation.

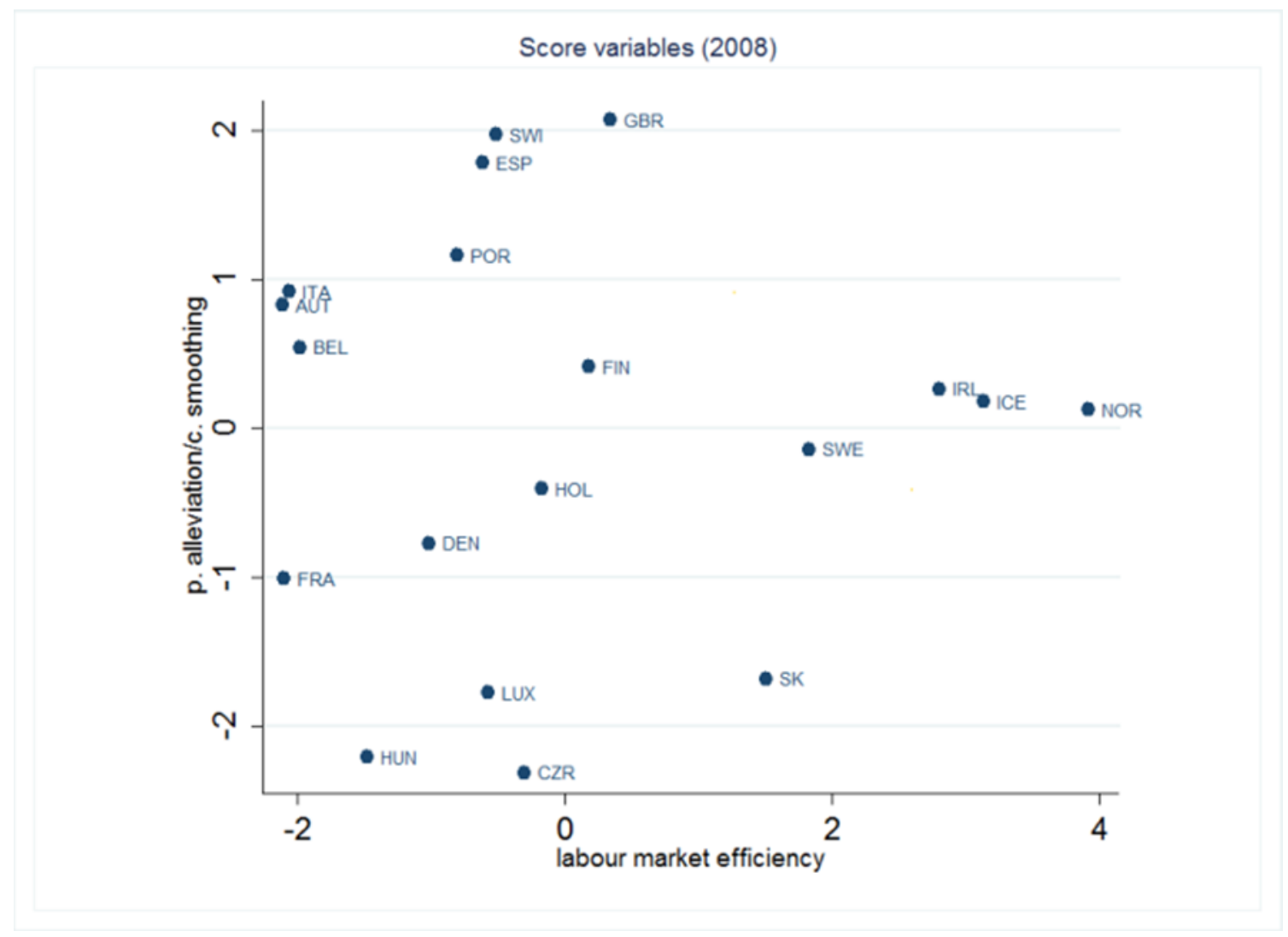

Figure 2. Score variables for countries in 2008

Source: Author's results.

Score plot (Figure 2 and Figure 3) for countries indicate that Sweden, Iceland, Norway and Ireland forms cluster for both 2008 and 2013. Those countries characterize high value on the labour efficiency axis and balance between consumption smoothing and poverty alleviation. In the year 2013 pension systems in Sweden, Iceland, Norway and Ireland are more efficient relatively to other European countries than in 2008 in terms of labour market. After financial crisis those countries varies much more on the poverty alleviation and consumption smoothing axis. Pension systems in Norway and Iceland are more poverty alleviation than before crisis. 


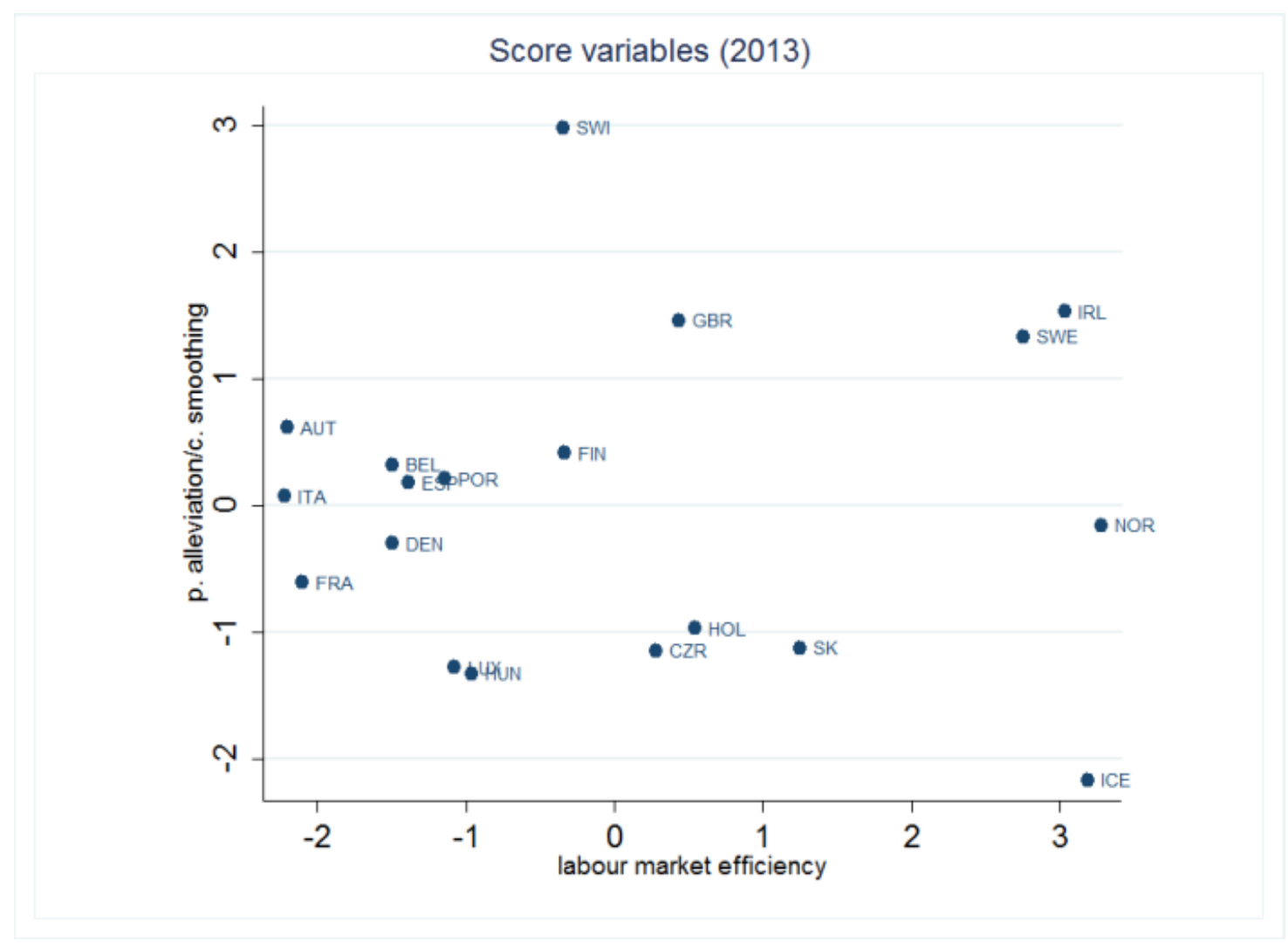

Figure 3. Score variables for countries in 2013

Source: Author's results.

\section{CONCLUSION}

The question: "Is there a Nordic pension system regime?" is still open. Many answers no, especially those, who look from the standard welfare state research perspective for example at the different private and public scheme sizes.

Around 2008 Sweden, Iceland and Norway took resolute reform to maintain workers on the labour market introducing flexible retirement age and other strong incentives to stay longer in workforce. This in consequence makes this country different in comparison rest of Europe.

From our analysis imply that all the Nordic Countries are not in one cluster, but Norway, Sweden and Iceland have similar pension system efficiency. Before 2008's crisis they were very efficient on labour market and compromise poverty alleviation and consumption smoothing. In 2013 those three countries remain very strong on labour market, but different on poverty alleviation.

Applied method - Principal Component Analysis - have some limitation, as there are a few tests verifying significance and its correctness is based mostly on interpretability, so future research on the interaction between labour market and pension system in the Nordic countries should be done.

\section{ACKNOWLEDGEMENT}

This paper forms part of the project funded by the National Science Centre (Poland) under Grant Number DEC-2011/01/B/HS4/05502. 


\section{REFERENCES}

Andersen, T.M., Määttänen, N., \& Valkonen, T. (2014). The Nordic model - challenged but capable of reform. Retrieved from http://www.diva-portal.org/smash/get/diva2:715939/FULLTEXT02.

Barr, N., \& Diamond, P. (2006). The economics of pensions. Oxford review of economic policy, 22(1), 15-39.

Chovancova, B., \& Arendas, P. (2015). Long Term Passive Investment Strategies as a Part of Pension Systems. Economics \& Sociology, 8(3), 55-67.-67. doi:10.14254/2071-789X.2015/8-3/4.

Chybalski, F. (2012). Measuring the multidimensional adequacy of pension systems in European countries. The Pensions Institute Cass Business School.

Chybalski, F. (2016). The Multidimensional Efficiency of Pension System: Definition and Measurement in Cross-Country Studies. Social indicators research, 128(1), 15-34. doi:10.1007/s11205-015-1017-3.

Cábelková, I., \& Strielkowski, W. (2013). Is the level of taxation a product of culture? A cultural economics approach. Society and Economy, 35(4), 513-529. https://doi.org/10.1556/SocEc.2013.0007

Ebbinghaus, B. (2012). Europe's transformations towards a renewed pension system. In: Giuliano Bonoli and David Natali (eds): The New Welfare State in Europe. Oxford: Oxford University Press, chapter 9. https://www.researchgate.net/profile/Bernhard_Ebbinghaus/publication/289306048_Europe\%27s_Tra nsformations_Towards_a_Renewed_Pension_System/links/577f68ea08ae5f367d36c396/Europes-

Transformations-Towards-a-Renewed-Pension-System.pdf accessed 3.05.2017

Espring-Anderson, G. (1990). The three worlds of welfare capitalism. Princeton, New Jersey: Princeton University Press

Geanakopolos, J., Mitchell, O.S., \& Zeldes, S.P. (1998). Social Security Money's Worth, Columbia Business School, PW 98-05.

Grech, A.G. (2013). How best to measure pension adequacy. Centre for Analysis of Social Exclusion, CASE/172. Retrieved $1.05 .2017 \quad$ from http://eprints.lse.ac.uk/51270/1/_Libfile_repository_Content_Grech,\%20AG_Grech_How_best_meas ure_2013.pdf.

Hicks, A., \& Kenworthy, L. (2003). Varieties of welfare capitalism. Socio-economic review, 1(1), 27-61.

Kaiser, H. F. (1974). An index of factorial simplicity. Psychometrika, 39(1), 31-36.

Kalyugina, S., Strielkowski, W., Ushvitsky, L., \& Astachova, E. (2015). Sustainable and secure development: facet of personal financial issues. Journal of Security \& Sustainability Issues, 5(2), 297-304. doi:10.9770/jssi.2015.5.2(14).

Larsen, M., \& Pedersen, P.J. (2015). Labor Force Activity after 60: Recent Trends in the Scandinavian Countries with Germany as a Benchmark, IZA Discussion Papers, No. 9393 http://hdl.handle.net/10419/124916, accessed 10.05.2017

Ledesma, R. D., Valero-Mora, P., \& Macbeth, G. (2015). The scree test and the number of factors: a dynamic graphics approach. The Spanish journal of psychology, 18, 1-10.

Nepp, A., Larionova, V., Okhrin, O., \& Sesekin, A. (2018). Optimal Pension System: Case Study. Economics and Sociology, 11(1), 267-292. doi:10.14254/2071-789X.2018/11-1/18 
Nilsson, K., Östergren, P. O., Kadefors, R., \& Albin, M. (2016). Has the participation of older employees in the workforce increased? Study of the total Swedish population regarding exit from working life. Scandinavian journal of public health, 44(5), 506-516. https:// doi.org/10.1177/1403494816637262.

NOSOSCO, P. G. (2008). Old-age Pension Systems in the Nordic Countries. Copenhagen. Retrieved from http://urn.kb.se/resolve?urn=urn:nbn:se:norden:org:diva-4604

Orszag, P. R., \& Stiglitz, J. E. (2001). Rethinking pension reform: Ten myths about social security systems. New ideas about old age security, 17-56.

Soede, A.J., Vrooman, J.C., Ferraresi, P.M., Segre, G., (2004), Unequal Welfare States Distributive consequences of population ageing in six European countries, Social and Cultural Planning Office, The Hague, June 2004 http://www.euro.centre.org/rescalingDocuments/files/ESP/Unequal Welfare States.pdf accessed 10.05.2017

Tabachnick, B.G., \& Fidell, L.S. (2007). Using Multivariate Statistics. Pearson Education, Inc.

Timonen, V., \& Kautto, M. (2014). Sustaining the Nordic welfare model in the face of population ageing [in] Harper, S., Hamoblin, K., International handbook on ageing and public policy. Cheltenham, UK.

Vrooman, C., \& Soede, A. (2008). Enepri Research Report NO. 54 AIM WP6, https://www.files.ethz.ch/isn/93990/RR\%20054.pdf, accessed 1.05.2017

Witkowska, D., \& Kompa, K. (2017). Polish Pension Market Performance in Comparison to Selected Benchmarks. Economics \& Sociology, 10(1), 35-47. doi:10.14254/2071-789X.2017/10-1/3.

World Bank. (1994). Averting the Old Age Crisis. Policies to Protect the Old and Promote Growth. Oxford University Press.

Zamuee, M. R. (2015). Efficiency of Pension Funds in Namibia. American Journal of Marketing Research, 1(3), $106-112$ 